\title{
Pelatihan Validasi Tes Kognitif Berbantuan Aplikasi SPSS 17.0 dan Aplikasi Anates Pada Guru SMAN 1 Singaraja
}

\author{
Nyoman Dantes ${ }^{\# 1}$, Ni Nyoman Lisna Handayani ${ }^{* 2}$, Ni Ketut Erna Muliastrini ${ }^{\# 3}$ \\ ${ }^{\#}$ Penelitian Evaluasi Pendidikan dan Pendidikan Dasar,Universitas Pendidikan Ganesha dan \\ Universitas Pendidikan Ganesha Singaraja \\ *Pendidikan Dasar, STAHN Mpu Kutruran Singaraja \\ 1dantes_nyoman@yahoo.ac.id \\ 3erna.muliastrini@undiksha.ac.id \\ ${ }^{2}$ lisnahandayani201@gmai.com
}

\begin{abstract}
Abstrak: Program ini merupakan program yang bersifat terminal dalam rangka peningkatan wawasan dan keterampilan guru-guru SMAN 1 Singaraja dalam melakukan validasi tes kognitif berbantuan aplikasi SPSS 17.0 dan aplikasi Anates. Di dalam pelaksanaannya, program ini akan mengacu pada pola sinergis antara tenaga pakar dan praktisi dari Undiksha dengan kalangan birokrasi dan administrasi pemerintah Kabupaten Buleleng, khususnya Kasubdin Pendidikan Dasar Dinas Pendidikan Nasional Kabupaten setempat. Di sisi lain, program ini juga diarahkan pada terciptanya iklim kerjasama yag kolaboratif dan demokratis dalam dimensi mutualis antara dunia perguruan tinggi dengan masyarakat secara luas di bawah koordinasi pemerintah Kabupaten setempat, khususnya dalam rangka peningkatan kinerja dan profesionalisme guru-guru SMAN I Singaraja secara cepat namun berkualitas bagi kepentingan pembangunan pendidikan di Kabupaten Buleleng. Berdasarkan rasional tersebut, maka program ini merupakan sebuah langkah inovatif dalam kaitannya dengan dharma ketiga perguruan tinggi, yaitu pengabdian kepada masyarakat.
\end{abstract}

Kata Kunci: SPSS 17.0, Anates, Tes Kognitif

\begin{abstract}
This program is a terminal program in order to increase the insights and skills of SMAN 1 Singaraja teachers in validating cognitive tests assisted by the SPSS 17.0 application and the Anates application. In its implementation, this program will refer to a synergistic pattern between experts and practitioners from Undiksha with the bureaucracy and administration of the Buleleng Regency government, especially the Head of the Basic Education Sub-Department of the local District National Education Service. On the other hand, this program is also directed at creating a collaborative and democratic climate of cooperation in a mutualist dimension between the world of higher education and society at large under the coordination of the local district government, especially in order to quickly improve the performance and professionalism of SMAN I Singaraja teachers. quality for the benefit of education development in Buleleng Regency. Based on this rationale, this program is an innovative step in relation to the dharma of the three universities, namely community service.
\end{abstract}

Keywords: SPSS 17.0, Anates, Cognitive Test

\section{PENDAHULUAN}

Pendidikan memegang peran penting

dalam meningkatkan kesejahteraan

masyarakat. Menurut Rousseau (Emile,

1762), tujuan utama pendidikan adalah

memberi kemampuan pada manusia untuk hidup di masyarakat. Kemampuan ini berupa pengetahuan dan/atau keterampilan, serta prilaku yang diterima masyarakat. Kemampuaan seseorang akan dapat berkembang secara optimal apabila memperoleh pengalaman belajar yang tepat. 
Untuk itu lembaga pendidikan dalam hal ini sekolah harus memberi pengalaman belajar yang sesuai dengan potensi dan minat peserta didik.

Pendidikan merupakan usaha sadar dan terencana untuk mewujudkan suasana pembelajaran dan proses pembelajaran agar peserta didik secara aktif mengembangkan potensi yang ada dalam dirinya (Mungin, 2012). Sehingga pendidikan memiliki peranan penting dalam upaya menciptakan kehidupan bangsa yang cerdas, damai, terbuka, dan demokratis

Upaya peningkatan mutu pendidikan diharapkan mampu meningkatkan harkat dan martabat manusia Indonesia. Oleh karena itu, pendidikan harus adaptif terhadap perkembangan dan perubahan zaman. Diera globalisasi, perkembangan ilmu pengetahuan dan teknologi yang cepat membawa dampak terjadinya revolusi informasi yang tidak lagi mengenal bantasan geografis dan kebangsaan. Sehingga dibutuhkan sumber daya manusia yang berkualitas dan mampu menghadapi perkembangan kemajuan zaman di segala bidang.

Sekolah sebagai lembaga pendidikan berfungsi sebagai lembaga sosial atau dapat dipandang sebagai lembaga ekonomi non profit. Sebagai lembaga sosial, sekolah memberikan pelayanan kebutuhan pendidikan dan pengajaran bagi masyarakat, sedangkan sebagai lembaga ekonomi, sekolah menghasilkan sumber daya manusia yang memiliki kompetensi ekonomi untuk hidup dan berkembang di tengah masyarakat.

Hal ini dilihat dari hasil pendidikan yang memiliki dampak sosial dan ekonomi kepada masyarakat. Dampak ekonomi dapat dilihat dari peningkatan kesejahteraan masyarakat. Dampak sosial dapat dilihat pada kehidupan bermasyarakat yang tenteram, aman, dan sentosa. Etika moral dan akhlak mulia masyarakat dapat dibangun melalui pendidikan, untuk memberi ketenteraman kepada masyarakat.

Faktor yang menentukan kualitas pendidikan antara lain kualitas pembelajaran dan karakter peserta didik yang meliputi bakat, minat, dan kemampuan. Kualitas pembelajaran dilihat pada interaksi peserta didik dengan sumber belajar, termasuk pendidik. Interaksi yang berkualitas adalah yang menyenangkan dan menantang. Menyenangkan berarti peserta didik belajar dengan rasa senang, sedangkan menantang berarti ada pengetahuan atau keterampilan yang harus dikuasai untuk mencapai kompetensi.

Alat evaluasi yang baik adalah alat evaluasi yang mampu menilai apa yang akan diassesmen, misalnya kemampuan yang akan dievaluasi adalah hasil belajar matematika siswa, maka soal yang dibuat harus sesuai dengan indikator belajar 
matematika pada suatu materi tertentu. Untuk membuat intrumen evaluasi yang baik perlu diperhatikan hal-hal sebagai berikut: 1) Instrumen yang dijadikan alat evaluasi harus valid atau sesuai dengan indikator pencapaian kompetensinya. Selain hal tersebut di atas, 2) menentukan tujuan tes; 3) menyusunan kisi-kisi soal dan rubrik skoring; 3) menelaahan soal; 4) uji coba soal dan validasi soal termasuk analisis-nya.

Validasi butir soal memiliki banyak manfaat diantaranya adalah 1) membantu responden untuk mengetahui kualitas tes yang digunakan, 2) mengetahui tingkat validitas sebuah instrumen, 3) soal dapat diperbaiki apabila tidak sesuai dengan materi yang dipelajari, 4) dapat meningkatkan validitas dan reliabilitas, 5) meningkatkan keterampilan membuat soal. Berdasarkan analisis soal yang dibuat oleh guru- guru di SMAN I Singaraja dapat diperoleh informasi tentang kualitas sebuah soal dan dapat dilakukan perbaikan, Validasi dan analisis instrumen demikian penting, namun dalam kenyataan masih banyak guru yang tidak melakukan validasi dan analisis instrumen sebelun digunakan.

Berdasarkan hal tersebut untuk meningkatkan kualitas tes yang digunakan untuk evaluasi, guru perlu menguasai penggunakaan software yang dapat mempermudah dalam melakukan validasi soal. Salah satu software yang dapat digunakan untuk analisis validasi butir soal adalah Anates. Berdasarkan dari hasil penelitian, guru-guru merasa antusias dan tertarik mencoba dan mempraktikkan langsung analisis butir soal pilihan ganda melalui metode SPSS dan Anates.

\section{RUMUSAN MASALAH}

Permasalahan pokok yang hendak diurai melalui program ini adalah: "seberapa efektifkah peningkatkan wawasan dan keterampilan guru-guru SMAN 1 Singaraja dalam proses pengembangan dan validasi tes kognitif dengan bantuan aplikasi SPSS 17.00 dan aplikasi Anates?

\section{METODE}

Program ini merupakan program yang bersifat terminal dalam rangka peningkatan wawasan dan keterampilan guru-guru SMAN 1 Singaraja dalam penembangan soal tes dan pelatihan aplikasi SPSS 17.00 dan aplikasi Anates untuk validasi tes kognitif. Untuk kepentingan pencapaian tujuan program ini, maka rancangan yang dipandang sesuai untuk dikembangkan adalah "RRA dan PRA" (rural rapid appraisal dan participant rapid appraisal). Di dalam pelaksanaannya, program ini akan mengacu pada pola sinergis antara tenaga pakar dan praktisi dari Undiksha dengan kalangan birokrasi dan administrasi pemerintah yang terkait, khususnya kepala 
sekolah SMAN I Singaraja. Di sisi lain, program ini juga diarahkan pada terciptanya iklim kerjasama yag kolaboratif dan demokratis dalam dimensi mutualis antara dunia perguruan tinggi dengan masyarakat secara luas, khususnya dalam rangka peningkatan kinerja dan profesionalisme guru-guru secara cepat namun berkualitas bagi kepentingan pembangunan pendidikan. Berdasarkan rasional tersebut, maka program ini merupakan sebuah langkah inovatif dalam kaitannya dengan dharma ketiga perguruan tinggi, yaitu pengabdian kepada masyarakat.

Program ini dirancang sebagai bentuk jawaban dan antisipasi dari berbagai permasalahan menyangkut kualitas dan kinerja guru SMAN 1 Singaraja, khususnya pada bidang penilaian. Berangkat dari rasional tersebut, maka program ini akan dilaksanakan dengan tim pelaksana untuk menyelenggarakan program peningkatan wawasan dan keterampilan guru-guru dalam melaksanakan pelatihan aplikasi SPSS 17.00 dan aplikasi Anates dalam rangka validasi tes kognitif, dengan mendatangkan para pakar dan praktisi pendidikan yang berkualifikasi secara standar di bidang aplikasi SPSS 17.00 dan aplikasi Anates. Model pelaksanaan kegiatan ini akan dilakukan secara langsung (tatap muka) dengan bidang kajian yang terkonsentrasi pada 2 (dua) topik dasar materi yaitu, wawasan dan pengetahuan guru tentang dasar-dasar pengembangan dan validasi tes dikotomi dan politomi, dan praktek penggunaan aplikasi aplikasi SPSS 17.00 dan aplikasi Anates untuk validasi tes kognitif.

Lama pelaksanaan kegiatan adalah 2 (dua) hari dengan melibatkan guru SMAN 1 Singaraja, yang jumlahnya berkisar antara 20-30 orang. Pada akhir program setiap peserta akan diberikan sertifikat sebagai tanda bukti partisipasi mereka dalam kegiatan ini. Melalui program ini, diharapkan para guru memperoleh penyegaran wawasan dan keterampilan dalam melaksanakan validasi tes dikotomi dan politomi untuk kepentingan tugas dan profesinya sebagai pengembang dan pelaksana kurikulum.

\section{HASIL PEMBAHASAN}

Hasil Registrasi peserta dilakukan dari pukul 08.00 - 08.30. Peserta berasal dari guru-guru sman I Singaraja di Kabupaten Buleleng. Pelatihan ini dilakukan melalui Google classroom. Pelatihan diikuti oleh 30 orang peserta sesuai daftar hadir peserta terlampir Kegiatan pelatihan Aplikasi SPSS ANATES untuk Validasi Tes Tipe Dikotomi pada Guru SMAN I Singaraja dimulai dengan pembuatan Google classroom, peserta join ke dalam akun 
google classroom, pengunggahan materi aplikasi ANATES. Adapun tampilan Google classroom adalah sebagai berikut.
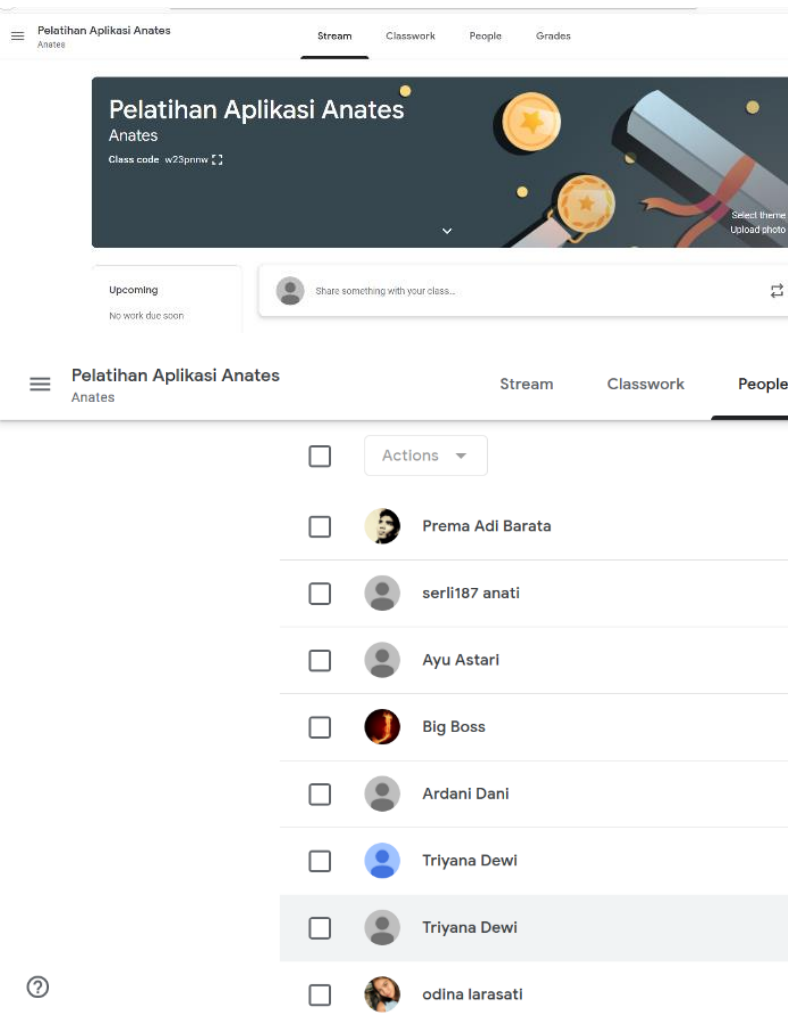

Gambar tampilan Google Classroom Narasumber dalam kegiatan pengabdian ini adalah Prof. Dr. Nyoman Dantes. Dalam pemaparannya beliau memaparkan Aplikasi ANATES. Pemaparan dimulai dengan pengantar perlunya evaluasi dilakukan secara berkelanjutan, evaluasi hasil pembelajaran dapat dilakukan setiap akhir pembelajaran, misalnya setelah selesai 1 bab materi, atau 1 kompetensi dasar, satu sub pokok bahasan, pada pertengahan semester, dan akhir semester. Bentuk tes yang digunakan sangat tergantung pada aspek apa yang ingin dinilai dan dievaluasi. Bentuk tes dapat berupa tes pilihan ganda maupun uraian untuk melihat hasil belajar yang mencakup materi dari awal hingga akhir bagian tertentu dari yang akan dievaluasi, atau tes dapat dilakukan untuk melihat kemampuan tertetu.

Alat evaluasi yang baik adalah alat yang dapat mengevaluasi apa yang akan dievaluasi, misalnya kemampuan yang akan dinilai adalah kemampuan berpikir kritis maka soal yang dibuat harus sesuai dengan indikator berpikir kritis. Apabila yang akan dilihat adalah bagaimana ketercapaian suatu kompetensi, maka soal atau instrument yang dijadikan alat evaluasi harus valid atau sesuai dengan indikator pencapaian kompetensinya.

Selain hal tersebut diatas, untuk membuat intrumen evaluasi yang baik perlu diperhatikan hal-hal sebagai berikut: 1) penentuan tujuan tes; 2) penyusunan kisikisi soal dan rubrik skoring; 3) penelaahan soal/ judgemen dari teman sejawat atau yang memiliki keahlian dibidang yang terkait; 4) uji coba dan validasi soal termasuk analisis-nya (Aiken, 1994). Kegiatan validasi butir soal memiliki banyak manfaat diantaranya adalah 1) membantu pengguna tes untuk mengetahui kualitas tes yang digunakan, 2) mendukung penulisan butir soal yang efektif, 3) soal dapat diperbaiki apabila tidak sesuai dengan materi yang dipelajari, 4) dapat 
meningkatkan validitas dan reliabilitas, 5) meningkatkan keterampilan membuat soal.

Pada tahap selanjutnya narasumber mulai memberikan contoh cara penggunaan aplikasi Anates validasi tes tipe dikotomi dengan langkah sebagai berikut.

Analisis Soal Dikotomi Menggunakan Program Anates

Mata Pelajaran: Bahasa Indonesia

Soal yang dianalisis adalah soal ujian sekolah kelas VI, dalam satu kelas terdapat 30 siswa.

1. Tampilan awal program Anates yaitu mengisikan jumlah subjek (siswa kelas VI).

2. Jumlah butir soal yang dianalisis yaitu 40 butir soal Ujian Sekolah Bahasa Indonesia yang mempunyai 5 pilihan jawaban (a,b,c,d, dan e).

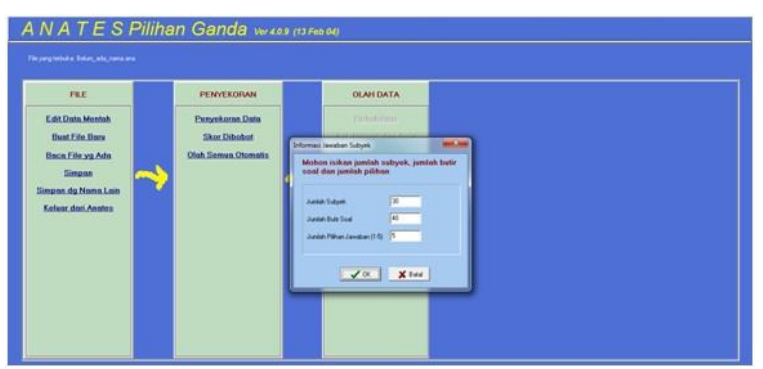

3. Input data dilakukan dengan memasukkan kunci jawaban pada kolom kunci dan nama peserta tes pada kolom nama subyek. Kemudian input butir jawaban peserta tes. Setelah selesai input data disimpan.

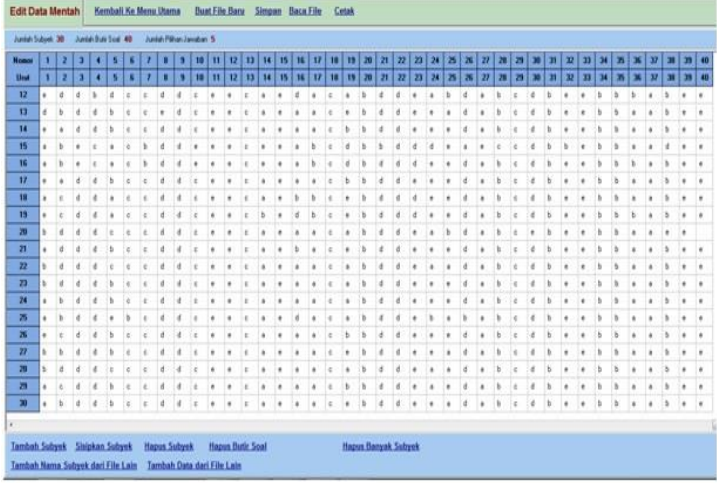

4. Apabila ingin melihat penyekoran dari data peserta tes klik kembali ke menu utama, klik penyekoran data, maka akan keluar tampilan seperti berikut:

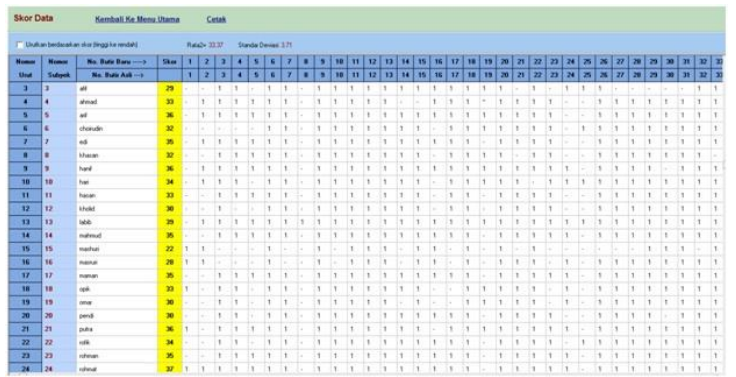

Skor 1 menunjukkan jawaban benar. Warna kuning menunjukkan skor yang diperoleh oleh masing-masing peserta tes.

5. Apabila ingin melakukan pembobotan jawaban, maka dari menu utama klik ganti bobot. Pada analisis ini bobot jawaban tiap butir soal adalah 2, maka nilai skor asli akan dikalikan 2 . 


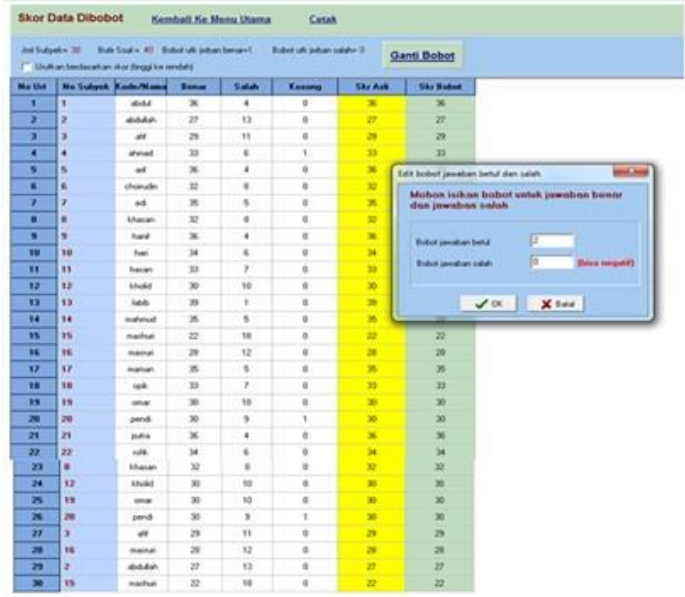

6. Untuk melakukan analisis data dari menu utama klik olah semua data otomatis, sehingga output data menjadi seperti berikut:

\section{a. Skor Data Dibobot}

Menunjukkan hasil jawaban peserta didik yang menjawab benar dan salah, skor asli, dan skor bobot pada masing-masing peserta tes.

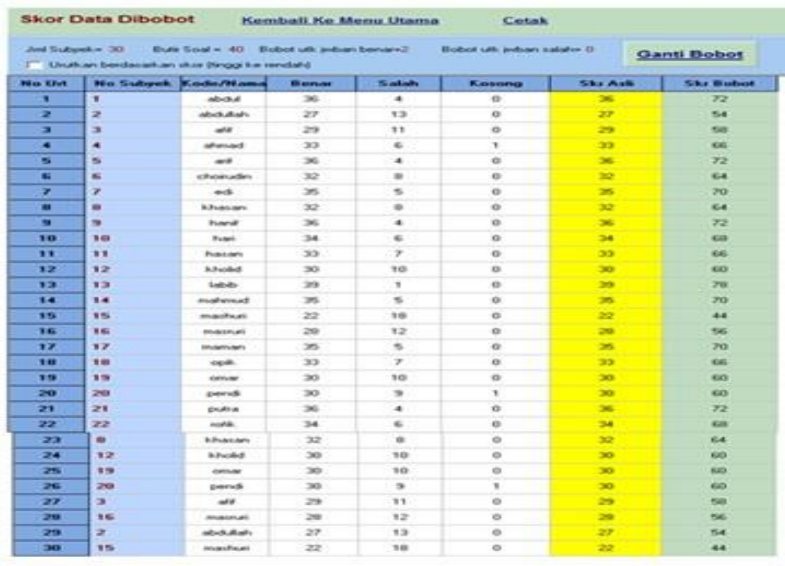

V SIMPULAN

Hal yang dapat disimpulkan dari hasil P2M ini yaitu peserta menyatakan bahwa melalui bantuan program aplikasi Anates dan SPSS sangat bermanfaat dan efektif untuk digunakan dalam melakukan validasi instrument penilaian. Hasil kegiatan pengabdian pada masyarakat ini akan memberikan kontribusi positif terhadap usaha peningkatan kualitas pendidikan khususnya dalam kaitan validasi tes tipe dikotomi dan politomi. Secara eksplisit kontribusi hasil kegiatan pengabdian masyarakat ini dapat dijabarkan sebagai berikut.

a) Bermanfaat dalam meningkatkan wawasan dan keterampilan mereka dalam pengembangan dan validasi tes kognitif dengan aplikasi SPSS 17.00 dan anates sehingga nantinya mereka dapat mengantisipasi sedini mungkin berbagai permasalahan yang berkaitan dengan tugas dan profesinya, serta meningkatkan produktivitasnya sebagai pengembang dan pelaksana kurikulum.

b) Pemerintah Kabupaten Buleleng, khususnya Dinas Pendidikan Nasional Kabupaten Buleleng, bahwa program ini dapat membantu merealisasikan salah satu program yang telah disusun dalam rencana pembangunan pendidikan Buleleng, khususnya pada jenjang sekolah menengah atas, yaitu peningkatan pengetahuan dan keterampilan guru dalam melakukan kegiatan-kegiatan akademis untuk menunjang tugas-tugas profesionalnya, sehingga secara langsung berdampak 
bagi peningkatan produktivitas pendidikan di Kabupaten Buleleng.

\section{DAFTAR PUSTAKA}

Arikunto, S. 2003. Managemen Penelitian. Jakarta: Rineka Cipta. --. 2005. Dasar-dasar Evaluasi Pendidikan (Edisi revisi, cetakan ke-5). Jakarta: Bumi Aksara.

---------. 2009. Dasar-Dasar Evaluasi Pendidikan. Yogyakarta: Bumi Aksara.

Blanchard. (2001). "Contextual Teaching and Learning". Makalah disampaikan dalam Workshop Contektual Learning di Wisata Hotel taggal 5 April 2001.

Dantes, 2012. Metode Penelitian. Yogyakarta: Andi Yogyakarta.

Effendi, Sofian., dan Singarimbun, Masri. (2011). Metode Penelitian Survai. Jakarta: LP3ES.

Gibbons, Michael. 1999. Elementary Education Relevance in the 21st Century. Paris: UNESCO and World Bank.

John Wiley \& sons: NY. Sudjanna, J. 1989, Statistika Teori dan Aplikasinya Jilid 1. Erlangga: Jakarta.

Johnson, R A. and Bhattacharyya, G.K.. 1992. Statistical Concepts and Methods.

Novalia, dan Syazali, Muhammad. (2014). Olah Data Penelitian Pendidikan. Bandar Lampung: AURA.

Sudijono, Anas. (2013). Pengantar Evaluasi Pendidikan. Bandung: Alfa Beta.

Sudjana, Nana. (2009). Penilaian Hasil Proses Belajar Mengajar. Bandung: PT Remaja Rosdakarya.

Sugiyono. (2012). Statistika Untuk Penelitian. Bandung: Alfa Beta.

Sukardi. (2011). Evaluasi Pendidikan: Prinsip dan Operasionalnya. Jakarta: Bumi Aksara.
Suprananto, Kusaeri. 2012.Pengukuran dan Penilaian Pendidikan. Yogyakarta: Graha Ilmu.

Syah, Muhibbin. (2006). Psikologi Pendidikan dan Pendekatan Baru. Bandung: PT Remaja Rosdakaya.

Tim Statistika Elementer. 2007. Modul Praktikum Statistika Elementer. Surakarta: FMIPA Press. 